\title{
Predictive Assessment of Toxicants Migration from Technogenic Gold-Mining Wastes (Case Study of the Tailings Management Facility of Tokur Mill, Amur Region, Russia)
}

\section{Valentina Ivanovna Radomskaya}

Institut geologii i prirodopol'zovaniâ DVO RAN: Institut geologii i prirodopol'zovania DVO RAN Lyudmila Mikhailovna Pavlova ( $\sim$ pav@ascnet.ru)

Institute of Geology and Nature Management Far Eastern Branch Rassian Academy of Sciences https://orcid.org/0000-0002-3734-1445

\section{Lyudmila Pavlovna Shumilova}

Institut geologii i prirodopol'zovaniâ DVO RAN: Institut geologii i prirodopol'zovania DVO RAN

\section{Elena Nikolaevna Voropaeva}

Institut geologii i prirodopol'zovaniâ DVO RAN: Institut geologii i prirodopol'zovania DVO RAN

Nina Aleksandrovna Osipova

Tomsk Polytechnic University: Nacional'nyj issledovatel'skij Tomskij politehniceskij universitet

\section{Research Article}

Keywords: Elements, Gold-Mining, Wastes, TMF, Migration, Extraction , Fraction, Predictive Assessment , Acidogenic and Acid-Neutralising Potentials

Posted Date: March 15th, 2021

DOI: https://doi.org/10.21203/rs.3.rs-202868/v1

License: (9) This work is licensed under a Creative Commons Attribution 4.0 International License.

Read Full License

Version of Record: A version of this preprint was published at Environmental Earth Sciences on November 8th, 2021. See the published version at https://doi.org/10.1007/s12665-021-10077-y. 
3

4 Radomskaya V.I. ${ }^{1}$ • Pavlova L.M. ${ }^{1}$ - Shumilova L.P. ${ }^{1}$ - Voropaeva E.N. ${ }^{1}$ O Osipova N.A. ${ }^{2}$

5

Predictive Assessment of Toxicants Migration from Technogenic Gold-Mining Wastes (Case

Study of the Tailings Management Facility of Tokur Mill, Amur Region, Russia)

${ }^{1}$ Institute of Geology \& Nature Management Far Eastern Branch Russian Academy of Sciences; 675000, Amur region,

Blagoveshchensk, Relochniy line, 1, Russia,

${ }^{2}$ National Research Tomsk Polytechnic University, 634050, Tomsk, Russia

Radomskaya V.I.

e-mail: radomskaya@ascnet.ru

Pavlova L.M. - correspondent

e-mail: pav@ascnet.ru

Shumilova L.P.

e-mail: $\underline{\text { shumilova.85@mail.ru }}$

Voropaeva E.N.

e-mail: levorglav@mail.ru

Osipova N.A.

e-mail: osipova-nina@yandex.ru

\section{Abstract}

The results of the toxic elements behavior predicting in gold mining technogenic waste during their draining with seasonal precipitation (case study of the tailings management facility of Tokur Mill, Amur Region, Russia) present in this article. The predictive assessment was made on characteristics basis of the tailings management facility material: the geochemical composition, migration ability of elements in model experiments using atomic emission and mass spectral methods, calculation of acid-producing and acid-neutralizing potentials. The substance of the tailing management facility has a high acid-neutralizing potential due to the carbonates in it, 
which contributes to the neutral and slightly alkaline drainage flows formation. Under these conditions, the migration of $\mathrm{Cd}, \mathrm{Bi}, \mathrm{Pb}, \mathrm{Sr}, \mathrm{Co}, \mathrm{Cu}, \mathrm{Ni}, \mathrm{Zn}, \mathrm{Sb}$ risk is low, and water migration of oxygen-containing As risk anions is very high, since the share of its mobile compounds in the tailings management facility material is 90 $92 \%$.

Keywords Elements $\bullet$ Gold-Mining $\bullet$ Wastes $\bullet$ TMF, Migration $\bullet$ Extraction $\bullet$ Fraction $\bullet$ Predictive Assessment - Acidogenic and Acid-Neutralising Potentials

\section{Introduction}

Adverse impact of mining on the environment is consistently increasing world-wide due to boost of production and processing of mineral resources. Mineral processing creates big amount of unusable waste (overburden rock, mill tailings). The waste is stored in dumps or tailings management facilities (TMFs) where it is kept for indeterminate time. As a rule, mining wastes contain compounds with toxic and hazardous elements, such as As, Cd, Cr, Cu, Hg, Pb, Ni, Zn and others (Jambor et al. 2003; Kapaj et al. 2006; Lottermoser 2007; Hoguet et al. 2013; Quansah et al. 2015). Being influenced by climatic factors, the mineral compounds in the dumps are intensively weathered and transform quite rapidly. When seasonal water flows (rainfall and snow-melt waters) interact with sulphide-bearing waste, acidic (sulphate) drainage waters are formed due to oxidation of sulphide minerals (pyrite, arsenopyrite, etc.) by the Eq. (1), (2):

$$
4 \mathrm{FeS}_{2}+15 \mathrm{O}_{2}+14 \mathrm{H}_{2} \mathrm{O}=4 \mathrm{Fe}(\mathrm{OH})_{3 \text { (solid) }}+16 \mathrm{H}^{+}+8 \mathrm{SO}_{4}^{2-}
$$

$$
6 \mathrm{FeAsS}_{(\text {solid })}+21 \mathrm{O}_{2}+24 \mathrm{H}_{2} \mathrm{O}=6 \mathrm{SO}_{4}{ }^{2-}+2 \mathrm{H}_{2} \mathrm{AsO}_{4}{ }^{-}+4 \mathrm{HAsO}_{4}{ }^{2-}+6 \mathrm{Fe}(\mathrm{OH})_{3(\text { solid })}+22 \mathrm{H}^{+}
$$

The formed acids, in their turn, dissolve other waste components which increases migration ability of toxic elements (Plyusnin and Gunin 2001; Corkhill and Vaughan 2009). In natural conditions, sulphuric acid leaching as one of geochemical processes in hypergenesis of ore-caused sulphide- 
bearing objects occurs imperceptibly. However, technogenesis steps them up tremendously. Precipitation leaking through the waste gets into surface and ground waters. With the drainage waters the released chemical elements and newly formed compounds migrate far beyond the dumps and TMFs. Seasonal water flows contribute to distribution of toxic elements tens and hundreds kilometres away from the source. It is difficult to predict how long the toxic elements of the stored waste will arrive in the environment. According to Yanin (1993), the process may last tens or hundreds of years depending on the quantity of sulphides, the rate of sulphide oxidation and the way the aggressive wastes get into water.

In the Upper Amur Basin, gold has been mined for a long period of time (over 160 years) and huge quantities of mining wastes, namely overburden rock dumps, tailing ponds and storages of slurry tailings from gold processing plants have been amassed, often next to residential areas. For a long time, up to 1988, gold mining in Russia was conducted with mercury to extract fine gold (amalgamation). The process comprising selective wetting of gold particles with mercury used to be a necessary part of traditional flow diagram/technological scheme of gold recovery. However, the equipment and facilities of the mines were mostly artisanal and there was hardly any standardized equipment (On termination... 1988). One of the most environmentally hazardous procedures was evaporating of mercury out of amalgamated gold which was conducted in retort ovens without any efficient condensing or mercury capturing system (Laperdina et al. 1995). Due to inferiority of the capturing systems, the mercury vapours were drifted into the tailings. In the Tokur Mill (Amur Region) gravity concentrate was amalgamated with mercury consumption 6-7 g per 1 tonne. In the period from 1969 to 1974 the mercury consumption in the mine amounted $3.070 \mathrm{~kg}$ (Koval et al. 2002). So, dumped mining wastes may be the source of chemical elements of different hazard category.

The main objective of the study was experimental determination of toxic elements mobility in technogenic gold-mining wastes (case study of the TMF of the Tokur Mill) in order to assess their possible migration into adjacent environments.

\section{Materials and methods}




\section{Characteristics of the site}

The study object is the tailings of gold-bearing ore of the Tokur Mill. Waste like pulp had been delivered to the TMF until the mine was suspended (2003). During years 1965-1996 2.548 thousand tonnes of processed rock were dumped in the TMF (Pavlova et al. 2016). The TMF consists of two plots (the old one and the new one) whose total length is $1.770 \mathrm{~m}$. The plots lie along the right bank of the Malyi Karaurak River, very close to the residential area of the settlement Tokur (Fig.1). In the north and east, the TMF is bounded by piled dams, in the west, there is a natural slope. Permeability of the dams rock is quite high as initially the dam was built with washed boulder and gravel deposits. As the TMF reservoir was filled, the walls of the dam were piled up by wastes from the Mill. In spring and summer the dam is intensively eroded by precipitation, the waters leak through the dam body into the Malyi Karaurak. The TMF surface lacks humic layer, vegetation like wormwood and poplar undergrowth is scarce.

Fig. 1 Map-scheme of the Tokur Mill tailings area: $\bullet 2$ - sample points

High permeability of the guard dam, formation of leakage channels and scours as well as overloading of the tailings facility several times resulted in the dam failure and spread of man-made waste as far as $3.5 \mathrm{~km}$ around the river valley. One of such failures caused flooding of lower and upper floodplain forests of the Malyi Karaurak. Heavy (about $0.5-1 \mathrm{~m}$ depth) silt-loam layer was formed which caused complete dieback of the forest stand. By now, the Mill wastes have spread with surface waters down the river to the Barandzha Brook. Spreading of the wastes out of the TMF may cause pollution of natural streams with not only suspensions but also highly-toxic elements. 
The TMF of the Tokur Mill is the integral part of technogenic ecosystem of the gold deposit Tokur. The deposit is located in the north-east of Amur Region in the geographical region called Mountain North. The landscape of the area is mountainous, having a lot of deep valleys and high hilly territories. Altitudes of the hills reach 700-1500 m, relative excess of watersheds over the valley bottoms is 400 $480 \mathrm{~m}$. The nearest mountain system is the Selemdzha Range. In hydrographic terms the area belongs to the Selemdzha River basin and its tributaries.

The climate of the region is continental with monsoon features of the distribution of annual precipitation. The hottest summer month is July, mean temperature reaches +15 to $+20{ }^{\circ} \mathrm{C}$, the highest attainable temperature is $+35{ }^{\circ} \mathrm{C}$. The coldest month is January, the temperature may go down to -56 ${ }^{\circ} \mathrm{C}$, 35-Centigrade temperatures last more than a month. Mean annual precipitation reaches $700 \mathrm{~mm}$; maximum precipitation (about 90\%) is in summer period; winters are dry; the snow cover reaches 50 cm depth.

The area is characterized by permafrost which in some places reaches $70-80$ or more metres depth. The permafrost has regular distribution, insignificant melting spots occur in large river valleys and on flat watersheds. In summer, frozen southern-slope ground melts $2-3 \mathrm{~m}$ depth, in poorly heated and marshy areas as well as in bogs and swamps - 0.6-1.2 $\mathrm{m}$ depth. Seasonal melting forms in the layer pore-stratal water whose impervious layer is permafrost. In the sites without drainage, the ground water horizon reaches daylight surface. In relatively dry sites, after rainfall and at the end of the summer season, $0.2-0.6 \mathrm{~m}$ depth soils are also water-abundant.

Hydrogeological conditions of the area are dependent on subpermafrost water of the seasonal melting layer. Water-bearing soils of the layer are loose alluvial and deluvial deposits of small thickness. All water-bearing subpermafrost horizons except alluvial soils freeze in the winter period.

The zonal soils of the region are mountain brown taiga illuvial-humic/Haplic Cambisols Dystric, intrazonal - alluvial-sod soils which form in the river plains. Brown taiga illuvial-humic soils (Fig. 1 point No 1) are shallow marginal, there is a lot of rock debris in it. According to texture they belong to gravel-stony loam with little percentage of silt. The main reason of stony texture is slow weathering of 
the rock. Alluvial-sod soils (Fig. 1 point No 2) are common in river-side plain of the Malyi Karaurak because while the placer was in progress the river plain landscape was damaged.

\section{Geology of Tokur deposit}

As ore composition and procedure of its recovery significantly influence element behavior in the TMF, geological and geochemical characteristics of the deposit.

Geological structure of the deposit and mineral composition of its ore have been specified before (Ejrish 2002; Ejrish et al. 2002; Ostapenko and Neroda 2007, 2016; Sorokin et al. 2011; Stepanov and Melnikov 2017), so we may only give brief profile. The Tokur deposit is sited in the east of MongolOkhotsk fold belt, in Selemdzha-Kerch gold zone. The deposit is confined to the southern wing of the Chelogorsk anticline of latitudinal strike (near its dome-shaped arch), composed of weakly metamorphosed sand-clay and siliceous deposits of the Tokur $\left(\mathrm{PZ}_{2-3} \mathrm{tk}^{2}\right)$ and Ekimchan $\left(\mathrm{PZ}_{2-3} \mathrm{ek}\right)$ suite of the Permian-Carboniferous age. Ore bodies are formed as a result of cementation and metasomatic substitution by ore quartz of crushing materials for longitudinal, slightly consonant tectonic zones. These are mineralized tectonites of breccia and banded texture. The fragments and lenses of the host rocks are cemented by quartz of various generations. Native gold is genetically associated with quartz. Besides quartz, the vein minerals present in the ores are adularia, sericite, chlorite and calcite. Ore minerals, which make up $1-3 \%$ of the ore volume, are represented by pyrite and arsenopyrite; sphalerite, galena, chalcopyrite, scheelite, pyrrhotite and fahl ores are less common, tin ore is very rare. Part of the gold in the intergrown and emulsion impregnation forms was enclosed in pyrite, arsenopyrite and galena. Primary ores, according to the mineralogical and geochemical composition, power and gold content, do not change much with depth.

\section{Study methods}


Sampling from the TMF was performed in the summer-autumn period from 2015 to 2016. Sampling points (Fig. 1) were located like this: points No 1, 2 (soil) sited above the deposit and the TMF level, and taken as background; points No 3, 4, 5, 6, 7 (industrial ground) are sited exactly in the old and new plots of the TMF. The material was collected from the 0-10-cm top layer by “envelope' technique (five samples are collected in the shape of an envelope) on the $10 \times 10 \mathrm{~m}$ area. Five samples were united into 1-kg sample. In points No 4 and 5 samples were collected layer-by-layer along the test pit to depths 80 and $230 \mathrm{~cm}$ respectively. The samples were thoroughly mixed to homogenize, quartered, one part was grounded to 200 mesh to determine element composition.

\section{Method for predictive assessment of element mobility}

To determine possible consequences of drainage influence on natural components the predictive assessment of toxic element mobility due to interaction of precipitation with the components of tailings is applied. The method is based on the experiments aimed at getting a quantitative of element leaching, element mobility in water and level of hazard which drainages cause to water reservoirs, water flows and soils (Sobek et al. 1978; Paktunc 1999; Hageman et al. 2015; Dold 2017). One of the methods used to predict drainage acidity is calculation of acidogenic and acid-neutralising potential of mining waste and tailings matter (Paktunc 1999; Alekseev et al. 2011; Edelev 2009, 2013; Bortnikova et al. 2018). Acidogenic value is widely used in environmental research (Skousen et al. 2002; Gaskova and Bortnikova 2007; Edelev 2013).

Acidogenic potential (AP) is a value of acid maximum which may develop as a result of hydrolytic oxidation of sulphites according to reactions 1-2 (Sobek et al. 1978). The value is calculated basing on sulphur concentration in the form of sulphites. The measurement unit is relative amount of calcium carbonate (kg per tonne of matter) required for acid neutralization according to the Eq. (3):

$\mathrm{AP}=10 \times \eta\left(\mathrm{S}_{\text {sulphide }}\right) \times \frac{\mathrm{M}\left(\mathrm{CaCO}_{3}\right)}{\mathrm{M}(\mathrm{S})} \approx 10 \times \eta\left(\mathrm{S}_{\text {sulphide }}\right) \times \frac{100}{32}=\eta\left(\mathrm{S}_{\text {sulphide }}\right) \times 31.25$, 
where 10 is conversion coefficient $\mathrm{kg} / \mathrm{t}$ into $\mathrm{wt} \% ; \eta\left(\mathrm{S}_{\text {sulphide }}\right)$ - sulphide sulphur concentration in the matter, wt $\% ; \mathrm{M}\left(\mathrm{CaCO}_{3}\right)$ and $\mathrm{M}(\mathrm{S})$ - calcium carbonate molar mass $(100 \mathrm{~g} / \mathrm{mol})$ and sulphur $(32 \mathrm{~g} / \mathrm{mol})$ respectively (Edelev 2013).

To calculate AP values in soil samples, the content of total and sulphate forms of sulphur was determined (Sulfur 1986). The sulphide sulphur content is calculated by the difference between total and sulphate sulphur.

The value of the acid-neutralising potential (ANP) is used to quantify the ability of a substance to neutralise acidic drainage (Sobek et al. 1978; Skousen et al. 2002) according to Eq. (4):

$\mathrm{H}^{+}+\mathrm{MCO}_{3 \text { (solid) }}=\mathrm{M}^{2+}+\mathrm{HCO}_{3}^{-}$,

in which $\mathrm{M}=\mathrm{Ca}^{2+}, \mathrm{Mg}^{2+}$.

Acid is mostly neutralised by carbonates, the most effective of which is calcite (Solomin and Krainov 1994). The value of $\mathrm{ANP}\left(\mathrm{kg} \mathrm{CaCO}_{3} / \mathrm{t}\right)$ is calculated using the Eq. (5):

$\mathrm{ANP}=\mathrm{n}\left(\mathrm{CaCO}_{3}\right)=10 \times \eta\left(\mathrm{CaCO}_{3}\right)$,

in which $\mathrm{n}\left(\mathrm{CaCO}_{3}\right)$ is the calcium carbonate content in the matter, $\mathrm{kg} / \mathrm{t} ; \eta\left(\mathrm{CaCO}_{3}\right)$ calcium carbonate content in the matter, \% (Paktunc 1999).

The content of carbonate minerals in the tailings samples was determined basing on the mineral analysis data.

The difference between AP and ANP is called actual acidogenic potential (AAP) (Sobek et al. 1978; Ritcey 2005), AAP = ANP - AP. The AAP value gives us an idea of the resulting acidity of the drainage in the future. Acidogenic is considered mineral matter of wastes with AAP $<-20 \mathrm{~kg} \mathrm{CaCO}_{3} / \mathrm{t}$. When the AAP value exceeds $20 \mathrm{~kg} \mathrm{CaCO}_{3} / \mathrm{t}$, neutral and weakly alkaline waters are formed (Skousen et al. 2002; Lengke et al. 2010; Edelev 2013). In the range $-20 \mathrm{~kg} \mathrm{CaCO}_{3} / \mathrm{t}<\mathrm{AAP}<20 \mathrm{~kg} \mathrm{CaCO} / \mathrm{t}$, the uncertainty area lies.

\section{Determination of element migratory potential}


Migratory potential of tailings toxic elements in the Tokur Mill was determined experimentally, by acting on it with different extractants. For the experiments, industrial ground from the old (point No 4) and new (point No 7) plots of the TMF was used, the ground was dried in air to constant weight. In the industrial ground samples, weak bounds in compounds of minerals and elements which under certain conditions may migrate into adjacent environments (natural waters or soils) were determined by the method of parallel extraction. The group of elements includes exchangeable, complex and specifically sorbed forms of elements which are extracted with various extractants. Element compounds form the following sequence according to the decrease of mobility within the group: water-soluble forms > exchangeable forms > complex forms > specifically sorbed forms (Radomskaya et al. 2016, 2017).

Water-soluble element compounds were extracted with snow-melted water ( $\mathrm{pH}$ 7.09), exchangeable - $1 \mathrm{M} \mathrm{NH}_{4} \mathrm{Ac}$ with $\mathrm{pH}$ 4.8. The extraction was carried out for 18 hours at $\mathrm{S} / \mathrm{L}=1: 5$ with periodic stirring, the solution was separated by centrifugation (7000 rpm) for $15 \mathrm{~min}$. In addition to exchangeable, complex (organomineral) element compounds were extracted with $1 \%$ solution of EDTA in ammonium acetate buffer ( $\mathrm{pH} 4.8)$. Based on the difference between the content of elements in $1 \%$ EDTA in $1 \mathrm{M} \mathrm{NH}_{4} \mathrm{Ac}$ and $1 \mathrm{M} \mathrm{NH}_{4} \mathrm{Ac}$ extracts, the quantity of elements in the composition of specifically sorbed forms of elements. Therefore, the number of specifically sorbed compounds was found by the difference between the number of elements extracted by hydrochloric acid $(1 \mathrm{M} \mathrm{HCl})$ and ammonium acetate (1 M NH 4 Ac) extracts (Madzhieva et al. 2014; Minkina et al. 2018). $1 \mathrm{M} \mathrm{HCl}$ extraction was carried out for 1 hour with constant stirring and at the ratio $S / L=1: 10$. To assess the potential reserve of toxic elements mobile compounds in industrial soils, their proportion in the gross content was calculated.

\section{Instrumental methods}


The elemental composition of the samples, the content of the main cations and trace elements in the extracts were determined by atomic emission (iCAP-6500, Thermo Scientific, USA) and mass-spectral (X-7, Thermo Elemental, USA) methods in the Analytical Certification Test Centre at the Institute of Microelectronics Technology and High Purity Metals of the Russian Academy of Sciences according to the methods of NSAM №520-AES/MS and NSAM №499-AES/MS. In the calculations, in cases when the element concentrations were below detection limit, the values equal half of the detection limit were used (Golovin et al. 2002).

Open leaching experiments may include unrecorded mercury losses (Gladyshev et al. 1974). Therefore, the thermoforms of mercury were determined in the initial material by atomic absorption (pyrolysis) on the mercury analyzer "PA-915+" with the attachment "PIRO-915+" (Lumex, Russia). This method allows us to identify the preferred forms of mercury in complex environments such as mineral soils (Bloom et al. 2003; Pinedo-Hernández et al. 2015). Mercury thermoforms were determined by increasing the temperature at an average heating rate of $0.8{ }^{\circ} \mathrm{C} / \mathrm{s}$. The detection limit of the method was $5 \mathrm{ng} / \mathrm{g}$.

Organic carbon in the samples was determined using a SHIMADZU TOC-V CPN (Shimadzu Corp., Japan) carbon analyzer using the SSM-5000A module.

\section{Results and discussion}

\section{Characteristics of industrial ground elemental composition}

Industrial soil of the TMF is represented by a rather homogeneous finely dispersed mass of greyishbrown colour. By texture, it is silty sand with predominant $(79.9 \%$ on average $)$ content of small and fine particles $(0.25-0.071 \mathrm{~mm})$ (Table 1$)$. The proportion of fine fractions increases with depth from 70.8 to $88.1 \%$. Occurrence of the larger $1-0.5 \mathrm{~mm}$ fractions is minimal and decreases TMF, mechanical degradation of large particles and their vertical fractional differentiation occurs in a sharply continental 
climate. Almost complete absence of organic and mineral colloids, poor compactness, lack of cohesive properties lead to high water permeability of the soil and contributes to its rapid erosion.

Table 1 Granulometric composition of the Tokur Mill tailings material

In the soil mineralogical composition (Table 2), rock fragments predominate in volume, consisting of intergrowths of quartz minerals, feldspar, amphibole, mica, and carbonate in various proportions. The quartz content is $8-32 \%$, feldspars - up to $21 \%$, calcite $-4-11 \%$, these minerals are often associated with iron hydroxide films. The content of sludge, which is detached-in-water clayeydusty material of dark brown colour, reaches $32 \%$. Ore minerals are insignificant.

Table 2 Mineral composition of the Tokur Mill tailings material, \%

The minimum and maximum contents of chemical elements in the tailings material do not have significant variations (Table 3). The greatest scatter was found in the $\mathrm{Hg}$ and $\mathrm{Bi}$ concentrations, the ratio of the maximum concentration to the minimum was 97 and 57.1 respectively. In conditionally background soils, the greatest variability was noted in the $\mathrm{CaO}$ content.

Compared with the upper continental crust (Table 3), the bulk composition of the tailings of the Tokur Mill is characterized by a relative deficiency of many elements - $\mathrm{Na}, \mathrm{Mg}, \mathrm{Al}, \mathrm{P}, \mathrm{Ca}, \mathrm{Sc}, \mathrm{Co}, \mathrm{Ni}$, $\mathrm{Rb}, \mathrm{Ga}, \mathrm{Sr}, \mathrm{Y}, \mathrm{Zr}, \mathrm{Nb}, \mathrm{Mo}, \mathrm{Cd}, \mathrm{Sn}, \mathrm{Cs}, \mathrm{Tl}, \mathrm{Th}, \mathrm{U}$ and heavy lanthanides. Significantly high concentrations of $\mathrm{As}, \mathrm{Sb}, \mathrm{W}, \mathrm{Bi}$ were observed, their concentration coefficients, calculated as the ratio of the average element content in soil samples to the conventional element clark in the upper continental crust (according to Taylor and MacLennan 1988), are 1005.4, 36.1, 16.3 and 5.2 respectively $\mathrm{Pb}, \mathrm{Ba}, \mathrm{Zn}, \mathrm{Cu}, \mathrm{Ni}, \mathrm{Cr}, \mathrm{V}$ concentrations in some samples exceed bulk earth values. Concentrations of other elements vary but insignificantly. Moreover, in some samples there was a certain deficiency of these elements, in others - an excess. 
The gross content of As and $\mathrm{Sb}$ in the soil is higher than similar indicators for conditionally

background soils and sanitary and hygienic standards. As concentration was 400-1640 times as high as the maximum admissible, Sb concentration - 1.2-2.7 times.

Exuberant As concentration in the conditionally background sites (4.5-19.4 maximum admissible) most likely indicates natural metallogenic features of the region. The calculated anomaly coefficients (Saet et al. 1986) reflect increase of average element concentration in the soil compared to the background soil. According to the obtained data (Table 3), anomaly level for $\mathrm{As}, \mathrm{W}, \mathrm{Hg}, \mathrm{Sb}$ is higher than for other elements.

\section{Assessment of acidogenic potential of the TMF industrial soil}

The hazard potential of tailings material for the environment determines the choice of environmental measures, therefore, the investigation of the processes occurring during the long-term interaction of waste and precipitation is of great importance. First of all, predictive assessment of drainage chemical composition can be given in terms of acidogenic and acid-neutralising potentials. For the calculation, data on the quantity of acidogenic (sulphides) and acid-neutralising (carbonates) mineral are used. Table 4 presents the AP and ANP values of the tailings material in the Tokur Mill.

Table 4 AP and ANP values $\left(\mathrm{kg} \mathrm{CaCO}_{3} / \mathrm{t}\right)$ in the tailings soil of the Tokur Mill

The results showed that all soil samples of the TMF are characterized by a high acid-neutralising potential due to the presence of carbonates. The maximum ANP values are characteristic of the soil from the tailings old site $\left(106 \mathrm{~kg} \mathrm{CaCO}_{3} / \mathrm{t}\right)$, the average $\mathrm{ANP}$ values are $81 \mathrm{~kg} \mathrm{CaCO}_{3} / \mathrm{t}$. AP values obtained in tailings soils vary in a narrow range from 0.2 to $12 \mathrm{~kg} \mathrm{CaCO}_{3} / \mathrm{t}$. Function of complex variable value indicates that neutral and weakly alkaline waters will form due to drainage of industrial soil in the TMF of the Tokur Mill by seasonal precipitation. 
In the $\mathrm{pH}$ range $6.5-8.5$ cationogenic toxicants $(\mathrm{Pb}, \mathrm{Cd}, \mathrm{Cu}, \mathrm{Ni}, \mathrm{Co}, \mathrm{Zn})$ have low migratory

ability as, according to the data (Shvartzev 1996), in the water with near-neutral pH, hydroxides whose solubility is low, form. In the similar conditions, concentrations of toxicants which form oxygenbearing anions (Cr, As, Se and $\mathrm{U})$ may reach much higher values. However, As takes a special position among the elements. It is characterised by high mobility due to the formation of mobile forms not only in oxidising, but also in reducing conditions (Charykova et al. 2008; Lindsay et al. 2015; Corkhill and Vaughan 2009).

\section{Assessment of chemical elements migration potential from the Tokur Mill tailings}

Determining the gross content of chemical elements is essential for the composition analysis of environmental objects. However, physicochemical mobility along with the element toxicity for natural objects, largely depend on its chemical form and type of connection with the substrate matrix. Contamination activity of the stored wastes for surface and ground waters is dependent on precipitation and atmospheric oxygen exposure. These factors significantly contribute to the intensive leaching and loss of elements. The number of weakly bound compounds of elements determines their volume that can migrate to adjacent environments and pollute them (Radomskaya et al. 2006; Minkina et al. 2008; Kulik and Radomskaya 2011a, 2011b). This group of elements includes water-soluble, exchangeable, complex and specifically sorbed forms of elements.

\section{Water-soluble forms of elements in the industrial soil}

The water-soluble fraction of the elements is considered to be the most dangerous and aggressive, as the rock matter is directly effected by precipitation and atmospheric oxygen. Subsequently, hydrogeochemical processes occurring in stored mineral wastes affect the composition of drainage water, ground and surface waters. Assay of water-soluble forms of toxic elements makes it possible to predict the specific impact which the tailings have on the environment. 

melt water varied from 7.9 to 8.3 from the tailings soils in the Tokur Mill. In such conditions, according to the data (Ryzhenko and Ryabenko 2013), dissolution reactions of minerals are the slowest, their rate ranges from $\mathrm{n} \times 10^{-3} \mathrm{~mol} / \mathrm{m}^{2} \mathrm{~s}$ (highly soluble salt minerals) to $\mathrm{n} \times 10^{-20} \mathrm{~mol} / \mathrm{m}^{2} \mathrm{~s}$ (poorly soluble minerals, oxides and silicates, phosphates, sulphides in a reducing environment, etc.). In addition, elements from minerals do not dissolve simultaneously: the rate of dissolution depends on the position of the element in the structure of the mineral. The interlayer cations are first to dissolve, then isomorphically substituting ions and ions occupying the peripheral zone of particles come. The ions that occupy the octahedral and tetrahedral fragments of the mineral structure migrate most slowly (Czuryupa 1973). In aqueous solutions, the elements are predominantly in the form of highly soluble secondary sulphates (Dold 2003; Bogush and Lazareva 2011), and soluble complex compounds with fulvic acids and inorganic ligands (Ladonin 2002).

The range of major and trace elements in the aqueous extracts is quite wide (Table 5). There is excess of $\mathrm{MAC}_{\mathrm{fw}}$ (maximum admissible concentrations of contaminants in the fishery waters) for some toxic elements (As, $\mathrm{Cu}, \mathrm{Pb}, \mathrm{V}$ and $\mathrm{Hg}$ ). Maximum As and $\mathrm{Hg}$ concentrations are 20-30 times as high as $\mathrm{MAC}_{\mathrm{fw}}$. In the solutions of all samples $\mathrm{Al}, \mathrm{Fe}$ and $\mathrm{Mn}$ exceeded $\mathrm{MAC}_{\mathrm{fw}}$.

The proportion of water-soluble forms of toxic elements from their gross content in the soil is: Cd 1.5-3.6\%, $\mathrm{Mo}-1.5 \%, \mathrm{Bi}-0.3-0.9 \%$ and $\mathrm{Sb}-0.6-0.9 \%$. Maximum content of water-soluble As and $\mathrm{Hg}$ reaches $0.5 \%$.

Thus, the drainage waters of the tailings can contain high concentrations of $\mathrm{As}, \mathrm{Hg}, \mathrm{Cu}, \mathrm{Mn}$, exceeding the MAC standards for harmful substances in the fishery water bodies.

Table 5 Content of elements in the water-soluble fraction

\section{Exchangeable forms of elements in the industrial soil of the TMF}


The fraction extracted with ammonium acetate $\left(1 \mathrm{M} \mathrm{NH}_{4} \mathrm{Ac}\right)$ simulates the effect of weakly acidic

377 solutions (weakly acidic drainage). Acid drainage can occur in those sites of the TMF where the rate of acid formation and its mass are greater than the rate of the acid neutralisation with carbonates, despite the higher content of carbonates in general. This process is possible in areas of passive and active water exchange due to the finely divided waste texture. Passive water exchange is favourable for the accumulation of products of sulphide sulphur oxidation, active - leaching of oxidation products from the soil and formation of acid drainage. Long-term interaction of the rock and water facilitates neutralisation processes.

Using a $1 \mathrm{M} \mathrm{NH}_{4} \mathrm{Ac}(\mathrm{pH} 4.8$ ) solution, the exchangeable, most mobile, forms of elements, which are represented by easily hydrolyzable compounds, are extracted (Kosheleva 2015). They pass into solution due to ion exchange as well as hydrolysis under the influence of hydrogen ions and formation of soluble acetate or ammonium complex compounds. The use of a slightly acidic buffer solution can lead to partial dissolution of carbonates and to the transfer of carbonate-related elements into the solution.

More trace (As, $\mathrm{Ni}, \mathrm{Cu}, \mathrm{Co}, \mathrm{Zn}, \mathrm{Pb}, \mathrm{Y}, \mathrm{Ce}, \mathrm{Hg}$ ) and major elements from the tailings soil (Table 6) passed into acetate-ammonium extracts than into the water-soluble fraction. In the fractional ratio, only $\mathrm{Li}, \mathrm{Ga}, \mathrm{V}, \mathrm{W}, \mathrm{Zr}, \mathrm{Ti}, \mathrm{Rb}$, and $\mathrm{Nb}$ have an insignificant part of exchangeable forms. For the remaining elements, the share of exchangeable forms in the gross contents is large, which indicates a high probability of their migration when exposed to acidic drainage solutions. $\mathrm{Cd}$ is one of the strongest genotoxic and cancinogenic elements, whereas, the share of its exchangeable forms reaches $70 \%$ of total $\mathrm{Cd}$ content in the soil. High extractability of $\mathrm{Cd}$ with ammonium acetate buffer has been reported (Plekhanova et al. 2001; Minkina et al. 2016). The latter is related to the ability of Cd cations to be part of very mobile chelate compounds that provide the transfer of this element. Major elements also have large share of exchangeable forms: $\mathrm{Ca}-45 \%, \mathrm{Mn}-32 \%, \mathrm{Sr}-36 \%$.

Acidic drainage solutions may form while sulphur from sulphide minerals (e.g. pyrite $\mathrm{FeS}_{2}$ ) is being oxidised to sulphuric acid by Eq. (1). According to the data of elemental analysis, the sulphur content in the tailings material ranges from 0.007 to $0.38 \mathrm{wt} \%$. However, the presence of calcite in the 
mill waste, the content of which varies from 4 to $11 \%$, contributes to the neutralisation of acid solutions by Eq. (4). The natural acid neutralisation will probably cause lower content of mobile forms of elements in the drainage solutions of the tailings in natural conditions than in experimental data.

Table 6 Average content of elements in exchangeable, organomineral and specifically sorbed fractions

\section{Organomineral forms of element in the industrial soil of the TMF}

Organomineral forms of elements (complex compounds) develop when organic matter interacts with mineral components. This process facilitates the transition of chemical elements of minerals into soluble, bioavailable forms. The number of organomineral forms is determined by the difference between the numbers of elements recovered by $1 \%$ EDTA in $1 \mathrm{M} \mathrm{NH}_{4} \mathrm{Ac}$ and $1 \mathrm{M} \mathrm{NH}_{4} \mathrm{Ac}$. According to the quantitative content of complex compounds ( $\%$ of gross content) in the tailings of the Tokur Mill, the elements form the following variation series: $\mathrm{As}>\mathrm{Pb}>\mathrm{Bi}>\mathrm{Na}>\mathrm{Co}>\mathrm{Mn}>$ $\mathrm{Cu}>\mathrm{Ca}>\mathrm{Cd}>\mathrm{Fe}>\mathrm{Sb}>\mathrm{Ni}>\mathrm{Zn}>\mathrm{Sr}>\mathrm{Ho}>\mathrm{Y}>\mathrm{Yb}>\mathrm{Dy}>\mathrm{Lu}>\mathrm{Er}>\mathrm{Tm}>\mathrm{Mg}>\mathrm{Mo}>\mathrm{Tb}>\mathrm{Th}$ $>\mathrm{Eu}>\mathrm{Gd}$. The share of organomineral $\mathrm{As}, \mathrm{Pb}$ and $\mathrm{Bi}$ reaches $1 / 3$ of their total content in the soil. Large proportion of As compounds in the fraction indicates high migration ability of the element. According to the data (Hess and Blanchar 1977), most soluble As compounds are found in flooded, rich in organic matter soils with $\mathrm{Eh}=25-100 \mathrm{mV}$. Organic molecules increase As bioavailability (Grafe et al., 2001). The relative content of the complex forms of the remaining elements is much lower: the proportions of $\mathrm{Zn}$ and $\mathrm{Ni}$ are $6-9 \%$ of the total content, which is explained by the weak complexing properties of these elements with organic matter (Piccolo and Stevenson 1982). Insignificant number of elements in the form of complex compounds can also be connected with low content of organic carbon in the tailings material.

\section{Specifically sorbed forms of elements in the industrial soil}


Significant part of specifically sorbed compounds is represented by elements loosely bound with oxides and hydroxsides of Fe, Al, Mn and carbonates (Minkina et al. 2008). This form may be considered intermediate or transitional to strongly bound compounds.

In the mineral matter of the TMF in the Tokur Mill among mobile compounds specifically sorbed forms prevail (Table 6). The proportion of the fraction for $\mathrm{As}, \mathrm{Ca}, \mathrm{Bi}$ and $\mathrm{Pb}$ is more than $50 \%$ of the gross content. Weakly bound compounds represent an important in ecological terms group. According to the indicator, potential risks of element migration into adjacent environment may be estimated. To assess the hazardous potential of the tailings from the Tokur Mill the proportion of mobile compounds to their total content was calculated. Based on this, it was revealed that $\mathrm{Ca}, \mathrm{Pb}, \mathrm{As}, \mathrm{Mn}, \mathrm{Bi}, \mathrm{Sr}$ and $\mathrm{Co}$ led in the share of weakly bound compounds. $\mathrm{Ca}$ is passed into solutions by calcite whose concentration in the tailings reaches $11 \%$. Slightly acidic solutions may cause partial calcite dissolution and $\mathrm{Ca}$ migration.

The total content of mobile forms of $\mathrm{Pb}$, As is $85-90 \%$ of their gross content, $\mathrm{Mn}, \mathrm{Bi}-70-80 \%$, $\mathrm{Cd}-64-99 \%, \mathrm{Co}-50-65 \%, \mathrm{Cu}-$ about $45 \%, \mathrm{Zn}, \mathrm{Ni}, \mathrm{Fe}, \mathrm{Sb}-30-36 \%, \mathrm{Mo}-17-20 \%, \mathrm{Cr}-5-7 \%$ of their gross content.

The proportion of specifically sorbed forms of $\mathrm{Mn}, \mathrm{As}, \mathrm{Pb}, \mathrm{Bi}$ in the composition of weakly bound compounds is 43-62\%. The exchangeable forms of $\mathrm{Cd}$ and $\mathrm{Sr}$ dominate in the composition of the compounds - up to $80 \%$ and 50\%, respectively. Ecologically hazardous contaminations of adjacent environments can be associated with both exchangeable and complex forms of Co, whose share among loosely bound compounds is $40-59 \%$.

The proportion of $\mathrm{Hg}$ mobile forms is $13-14 \%$. Most $\mathrm{Hg}$ is contained in the bottom fraction which indicates its poor solubility in the tailings soil. Despite of this, there is a high risk of the $\mathrm{Hg}$ mobile forms getting into water intakes with ground waters while it is leached from technogenic dumps.

\section{Mercury forms in the industrial soil of the Tokur TMF}


The method of mercury thermal sublimation from solid samples makes it possible to determine the potential forms of $\mathrm{Hg}$ on various matrices (Shuvaeva et al. 2008; Reis et al. 2012; Rumayor et al. 2013). $\mathrm{All} \mathrm{Hg}$ forms are divided into relative groups depending on the temperature of sublimation (maximum yield temperature $(\mathrm{Tm})$. At low $\operatorname{Tm}\left(150-160{ }^{\circ} \mathrm{C}\right)$ free mercury is sublimated. At $\mathrm{Tm}=250-290{ }^{\circ} \mathrm{C}$, physically sorbed $\mathrm{Hg}$ compounds are sublimated. The destruction of chemisorbed forms of $\mathrm{Hg}$ according to thermal destruction data occurs at $\mathrm{Tm}=310-320^{\circ} \mathrm{C}$. At $\mathrm{Tm}=350-410{ }^{\circ} \mathrm{C} \mathrm{Hg}$ sulphides are sublimated (Tauson et al. 1992; Tauson et al. 1994). Shuvaeva et al. (2008) showed on the modelled mixtures of individual mercury compounds $\left(\mathrm{HgX}_{2}\left(\mathrm{X}=\mathrm{Cl}^{-}, \mathrm{N}, \mathrm{S}\right), \mathrm{HgO}, \mathrm{CH}_{3} \mathrm{HgCl}\right.$ and $\left.\mathrm{HgS}\right)$ that $\mathrm{HgX} 2$ and $\mathrm{HgO}$ during thermal destruction extract in the same temperature range $\left(50-150{ }^{\circ} \mathrm{C}\right)$, methylmercury - at $150-230{ }^{\circ} \mathrm{C}, \mathrm{Hg}$ sulphide - at $190-280{ }^{\circ} \mathrm{C}$. Rumayor et al. (2013) obtained thermal desorption profiles of fifteen mercury compounds: $\operatorname{HgI}_{2}\left(100^{\circ} \mathrm{C}\right)<\mathrm{HgBr}_{2}\left(110^{\circ} \mathrm{C}\right)<\mathrm{Hg}_{2} \mathrm{Cl}_{2}\left(119{ }^{\circ} \mathrm{C}\right)$ $<\mathrm{HgCl}_{2}\left(138{ }^{\circ} \mathrm{C}\right)<\mathrm{Hg}(\mathrm{CN})_{2}\left(267^{\circ} \mathrm{C}\right)<\mathrm{HgCl}_{2} \mathrm{O}_{8} \cdot \mathrm{H}_{2} \mathrm{O}\left(273{ }^{\circ} \mathrm{C}\right)<\mathrm{Hg}(\mathrm{SCN})_{2}\left(288^{\circ} \mathrm{C}\right)<\mathrm{HgS}($ red $)$ $\left(305^{\circ} \mathrm{C}\right)<\mathrm{HgF}_{2}\left(234 ; 449{ }^{\circ} \mathrm{C}\right)<\mathrm{Hg}_{2}\left(\mathrm{NO}_{3}\right)_{2} \cdot 2 \mathrm{H}_{2} \mathrm{O}\left(264 ; 427{ }^{\circ} \mathrm{C}\right)<\mathrm{Hg}\left(\mathrm{NO}_{3}\right)_{2} \cdot \mathrm{H}_{2} \mathrm{O}\left(215 ; 280 ; 460{ }^{\circ} \mathrm{C}\right)$ $<\mathrm{HgO}$ (yellow, red) $\left(284 ; 469^{\circ} \mathrm{C}\right)<\mathrm{Hg}_{2} \mathrm{SO}_{4}\left(295 ; 514{ }^{\circ} \mathrm{C}\right)<\mathrm{HgSO}_{4}\left(583{ }^{\circ} \mathrm{C}\right)$.

When determining the forms of $\mathrm{Hg}$ in complex, complicated in composition, objects, this method has limitations since the thermal peaks of slightly different $\mathrm{Hg}$ compounds overlap, and Tm depends on the composition of the sample matrix (Shuvaeva et al. 2008). Nevertheless, in the tailings material, by the method of thermal sublimation, it was possible to determine three types of forms of mercury (Fig. 2). The first type is represented by one thermoform, the second - contains two thermoforms, the third - three. The content of mercury forms was determined by integration. With incomplete separation of the peaks, the calculation was performed by doubling the area of the triangle, where one side is the height of the poorly divided peak.

Fig. 2 Types of mercury thermoforms

According to the data obtained (Fig. 2), mercury desorption was mainly observed in the temperature range $130-460{ }^{\circ} \mathrm{C}$. Maximum $\mathrm{Hg}$ desorption which amounts $75-100 \%$ was observed in 
the range $190-230{ }^{\circ} \mathrm{C}$. This peak corresponds to the form of physically adsorbed divalent mercury. The range $\mathrm{Tm}=150-250{ }^{\circ} \mathrm{C}$ is characteristic of thermal desorption methylmercury. However, low content of organic carbon in the tailings material $(0.09-0.3 \%)$ indicates the bound of $\mathrm{Hg}$ with mineral components of the waste. $\mathrm{Hg}$ thermal form in the Tm range $250-270{ }^{\circ} \mathrm{C}$ is attributed to chemisorbed mercury, its share is $5-17 \%$. In some soil samples, small share of mercury was found (3-6\%) in the form of $\mathrm{HgS}$ (the peak with the maximum Tm ranges $370-410{ }^{\circ} \mathrm{C}$ ). Thus, three forms of mobile $\mathrm{Hg}$, having unequal quantitative distribution, are determined in the tailings material of the Tokur Mill, among which oxidised, physically sorbed, predominate.

\section{Conclusion}

The tailings material of the Tokur Mill is made up of soft, permeable silty sand. The concentration of fine and small fractions $(0.25-0.071 \mathrm{~mm})$ makes up $80-88 \%$ whose proportion increases with depth. In mineral composition of the soil, rock fragments dominate (up to 59\%), there is quartz (up to $32 \%$ ), feldspars (up to $21 \%$ ), calcite (11\%) and insignificant quantity of ore minerals (up to $0.2 \%$ ). In the element composition of the soils compared to UCC high concentrations of As, $\mathrm{Sb}, \mathrm{W}$, Bi are found, their concentration coefficients are 1005.1, 36.1, 16.3 and 5.2 respectively. Concentrations of $\mathrm{Pb}, \mathrm{Ba}$, $\mathrm{Zn}, \mathrm{Cu}, \mathrm{Ni}, \mathrm{Cr}, \mathrm{V}$ in some samples are higher than bulk earth values. As for sanitation and hygiene regulations, As is 400-1640 times higher and $\mathrm{Sb}$ is $1.2-2.7$ times higher than MAC.

Assessment of the potential of chemical elements to migrate from a industrial soil of the TMF showed that $\mathrm{Cr}, \mathrm{Mo}, \mathrm{Sb}, \mathrm{Zn}, \mathrm{Ni}, \mathrm{Cu}$ in unstable compounds (water-soluble, exchangeable, organomineral and specifically sorbed fractions) make up 7-46\%, whereas $\mathrm{Co}, \mathrm{Sr}, \mathrm{Pb}, \mathrm{Bi}, \mathrm{Cd}, \mathrm{As}-$ 60-90\%. This fact indicates a high degree of risk that these elements will migrate to adjacent environments during the draining of the tailings matter by seasonal precipitation.

Applying pyrolysis, three forms of mercury are identified in the tailings material, among which 75-100\% are physically sorbed $\mathrm{Hg}^{2+}, 5-17 \%$ are chemisorbed, and 3-6\% are mercury sulphide. Assessment of the mercury migration potential shows that up to $87 \%$ of its compounds are in the 
residual fraction. However, the insignificant $(0.4-1.2 \%)$ proportion of water-soluble and exchangeable compounds of mercury does not reduce its toxicity when it enters water flows.

The presence of a significant amount of carbonates (11\%) in the tailings material causes a high acid-neutralising potential of the industrial soil, due to which, the probability of acid drainage formation is low. The formation of neutral and slightly alkaline effluents increases the risk of migration of oxygen-containing As anions. The proportion of its mobile compounds in the tailings material is 90 $92 \%$.

Conflict of Interest The authors declare that they have no conflict of interest.

\section{References}

Alekseev VA, Kochnova LN, Bychkova YaV, Krigman LV (2011) Experimental study of normalized elements extraction by water from contaminated rocks. Geochem Inter 12:1317-1342

Bloom NS, Preus E, Katon J, Hiltner M (2003) Selective extractions to assess the biogeochemically relevant fractionation of inorganic mercury in sediments and soils. Anal Chim Acta 479(2):233248. doi:10.1016/s0003-2670(02)01550-7

Bogush AA, Lazareva EV (2011) Behavior of heavy metals in sulfide mine tailings and bottom sediment (Salair, Kemerovo region, Russia). Environ Earth Sci 64(5):1293-1302

Bortnikova SB, Silantyeva NV, Zapolsky AN (2018) Asessment of acid-base accounting of mine waste rocks and mobility of potentially toxic elements of the Razdolinsky ore field (Krasnoyarsk territory). Bulletin of the Tomsk Polytechnic University, Geo Assets Engineering 329(12):5572. doi.org/10.18799/24131830/2018/12/20

Charykova MV, Krivovichev VG, Depmaejr V (2008) Physicochemical conditions for formation of arsenic minerals in near-surface environments (in Russian). Vestnik of Saint Petersburg University, Ser 7 Geology, Geography 4:62-81

Corkhill CL, Vaughan DJ (2009) Arsenopyrite oxidation - a review. Appl Geochem 24:2342-2361 
Czuryupa IG (1973) Role of microorganisms in aluminosilicates weathering and the formation of mobile easily migrating compounds (in Russian). Weathering crust Iss 13:3-38

Dold B (2003) Speciation of the most soluble phases in a sequential extraction procedure adapted for geochemical studies of copper sulfide mine waste. J Geochem Explor 80(1):55-68

Dold B (2017) Acid rock drainage prediction: a critical review. J Geochem Explor 172:120-132

Edelev AV 2009 Using of ore-processing industry waste solid matter analysis results to predict chemical composition of drainage waters. Chemistry for Sustainable Development 17:487-494

Edelev AV (2013) Predictive assessment of drainage waters composition interacting with sulfidecontaining matter. Russ Geol Geophys 54(1):144-157

Ejrish LV (2002) Metallogeny of gold in the Amur Region (in Russian). Dalnauka, Vladivostok, p 194 Ejrish LV, Ostapenko NS, Moiseenko VG (2002) Tokur gold ore deposit (Far East, Russia). Geology of Ore Deposits 44(1):50-52

Gaskova OL, Bortnikova SB (2007) On the quantitative determination of host rocks neutralizing potential. Geochem Inter 45(4):461-464

Ginsburg A I (Ed) (1970) Minerals and rocks of the USSR (in Russian). Thought, Moscow, p 439

Gladyshev VP, Leviczkaya SA, Filippova LM (1974) Analytical chemistry of mercury (in Russian). Nauka, Moscow, $231 \mathrm{p}$

GN 2.1.7.2041-06 (2006) Maximum Permissible Concentration (MPC) of Chemical Substances in the Soil (in Russian). Publishing Standards, Moscow, $15 \mathrm{p}$

Golovin AA, Moskalenko NN, Achkasov AI et al (2002) Requirements for the production and results of multipurpose geochemical mapping of 1: 200000 scale (in Russian). IMGRE, Moscow, p 92

Grafe M, Eick MJ, Grossel PR (2001) Adsorption of arsenate(V) and arsenite(III) on goethite in the presence and absence of dissolved organic carbon. Soil Sci Soc Am J 65:1680-1687

Hageman PL, Seal RR, Diehl SF, Piatak NM, Lowers HA (2015) Evaluation of selected static methods used to estimate element mobility, acid-generating and acid-neutralizing potentials associated with geologically diverse mining wastes. Appl Geochem 57:125-139. doi:10.1016/j.apgeochem.2014.12.007 
Hess RE, Blanchar RW (1977) Dissolution of arsenic from water logged and aerated soil. Soil Sci Soc Am J 41:861-865

Hoguet J, Keller JM, Reiner JL, Kucklick JR, Bryan CE, Moors AJ, Pugh RS, Becker PR (2013) Spatial and temporal trends of persistent organic pollutants and mercury in beluga whales (Delphinapterus leucas) from Alaska. Sci Total Environ 449:285-294

Jambor JL, Blowes DW, Ritchie AIM (Eds) (2003) Environmental aspects of mine wastes. Mineralogical Assoc. of Canada, Short Course Series 31, 430 p

Kapaj S, Peterson H, Liber K, Bhattacharya P (2006) Human health effects from chronic arsenic poisoning - a review. J of Environ Sci and Health. Part A: Toxic. Hazardous Substances and Environ Engineering 41(10):2399-2428. doi:10.1080/10934520600873571

Kosheleva NE, Kasimov NS, Vlasov DV (2015) Factors of the accumulation of heavy metals and metalloids at geochemical barriers in urban soils. Eur Soil Sci 48(5):476-492

Koval AT, Pavlova LM, Radomskaya VI, Radomskii SM, Kuimova NG, Krylov AV (2002) Mercury in ecosystems of Amur Region (in Russian). Bulletin of the Far Eastern Branch of the Russian Academy of Sciences 4:94-103

Kulik EN, Radomskaya VI (2011a) The study of modes of heavy metals occurrence in the brown forest soil under anthropogenic impact (in Russian). Agricultural Research Magazine 7:12-15

Kulik EN, Radomskaya VI (2011b) Features of heavy metals translocation into legumes under anthropogenic impact (in Russian). The Bulletin of KrasGAU 8 :83-88

Ladonin DV (2002) Heavy metal compounds in soils: problems and methods of study. Eur Soil Sci 35(6):605-613

Laperdina TG, Tupyakov AV, Egorov AI, Melnikova MV, Askarova OB, Banshhikov VA, Xvostova TE, Cybikdarzhiev Zh, Bochko OK (1995) Mercury pollution of environment in the zones of Transbaikalia gold mining enterprises influence (in Russian). Chemistry for Sustainable Development 3(1-2):57

Lengke MF, Davis A, Bucknam C (2010) Improving management of potentially acid generating waste rock. Mine Water Environ 29(1):29-44 
Lindsay MBJ, Moncur MC, Bain JG, Jambor JL, Ptacek CJ, Blowes DW (2015) Geochemical and mineralogical aspects of sulfide mine tailings. Appl Geochem 57:157-177 doi:10.1016/j.apgeochem.2015.01.009

Lottermoser BG (2007) Mine wastes: characterization, treatment and environmental impacts. Springer, Berlin, $314 \mathrm{p}$

Mandzhieva SS, Minkina TM, Motuzova GV, Golovatyj SE, Miroshnichenko NN, Lukashenko NK, Fateev AI (2014) Fractional and group composition of zinc and lead compounds as an indicator of the environmental status of soils. Eur Soil Sci 47(5):511-518

Minkina TM, Motuzova GV, Nazarenko OG, Kryshhenko VS, Mandzhieva SS (2008) Forms of heavy metal compounds in soils of the steppe zone. Eur Soil Sci 41(7):708-716

Minkina TM, Fedorov YuA, Nevidomskaya DG, Mandzhieva SS, Kozlova MN (2016) Specific features of content and mobility of heavy metals in soils of floodplain of the Don River. Arid Ecosystems 6(1):70-79

Minkina TM, Mandzhieva SS, Burachevskaya MV, Bauer TV, Sushkova SN (2018) Method of determining loosely bound compounds of heavy metals in the soil. Methods X 5 217-226. doi:10.1016/j.mex.2018.02.007

On termination of mercury use (amalgamation) in technological processes during the gold-bearing ores and sands beneficiation (in Russian) (1988) Order of the Main Directorate of Precious Metals and Diamonds under the Cabinet of Ministers of the USSR N 124 dated 29.12.1988 (in Russian).

Ostapenko NS, Neroda ON (2007) Fluid pressure and hydrorupture of rocks in hydrothermal mineralization (as exemplified by gold deposits). Russ J Pacific Geol 26(3):89-105

Ostapenko NS, Neroda ON (2016) Deposition conditions and features of distribution native gold individuals in the veins of Tokur mesothermal deposit (Russia). Geology of Ore Deposits 58(3):239-250. doi: 10.7868/S0016777016030072

Paktunc AD (1999) Mineralogical constraints on the determination of neutralization potential and prediction of acid mine drainage. Environ Geol 39(2):103-112. doi:10.1007/s002540050440 
Pavlova LM, Radomskaya VI, Shumilova LP (2016) The biotic factor in the environmental assessment of technogenic territory (on the example of tailing ponds of Tokur gold recovery plant). Izvestia RAS SamSC 18(2-2):467-477

Piccolo A, Stevenson FJ (1982) Infrared spectra of $\mathrm{Cu}^{2++}, \mathrm{Pb}^{2+}$ and $\mathrm{Ca}^{2+}$ complexes of soil humic substances. Geoderma 27(3):195-208

Pinedo-Hernández J, Marrugo-Negrete J, Díez S (2015) Speciation and bioavailability of mercury in sediments impacted by gold mining in Colombia. Chemosphere 119:1289-1295 doi:10.1016/j.chemosphere.2014.09.044

Plexanova IO, Klenova OV, Kutukova YuD (2001) Influence of sewage sludge on the content and fractional composition of heavy metals in sandy loam and soddy-podzolic soils. Eur Soil Sci $4: 496-503$

Plyusnin AM, Gunin V I (2001) Natural hydrogeological systems, formation of the chemical composition and response to technogenic impact (case study Transbaikalia) (in Russian). BNCz SO RAN, UlanUde, $137 \mathrm{p}$

Quansah R, Armah FA, Essumang DK, Luginaah I, Clarke E, Marfo K, Cobbina SJ, NketiahAmponsah E, Namujju PB, Obiri S, Dzodzomenyo M (2015) Association of arsenic with adverse pregnancy outcomes-infant mortality: a systematic review and meta-analysis. Environ Health Perspect 123:412-421. https://dx.http://dx.doi.org/10.1289/ehp.1307894

Radomskaya VI, Moiseenko NV, Radomskii SM, Krylov AV, Katola VM, Moiseenko VG (2006) The effect of sewage sludge on the behavior of heavy metals in the soil-plant system (in Russian). Agricultural Research Magazine 1:77-84

Radomskaya VI, Radomskii SM, Kulik EN, Pavlova LM (2016) Distribution and migration of toxic elements in soil-plant system at the Albynskoe gold deposit (Amur Region). Geography and Natural Resources 3:62-69. doi: 10.21782/GiPR0206-1619-2016-3(62-69)

Radomskaya VI, Radomskii SM, Pavlova LM, Kulik EN (2017) Specific features of rare-earth elements migration in natural and technogenic ecological systems. The case of Albynskoe gold 
deposit, the Amur Region (in Russian). Geoekologiya. Inzhenernaya Geologiya. Gidrogeologiya. Geokriologiya 1:15-27

Reis AT, Coelho JP, Rodrigues SM, Rocha R, Davidson CM, Duarte AC, Pereira E (2012) Development and validation of a simple thermo-desorption technique for mercury speciation in soils and sediments. Talanta 99:363-368

Ritcey GM (2005) Tailings management in gold plants. Hydrometallurgy 78(1-2):3-20. doi:10.1016/j.hydromet.2005.01.001

Rumayor M, Diaz-Somoano M, Lopez-Anton MA, Martinez-Tarazona MR (2013) Mercury compounds characterization by thermal desorption. Talanta 114:318-322

Ryzhenko BN, Ryabenko AE (2013) Modeling the composition of mine (waste rock) water at the deposits of the Balkhach gold-bearing field. Geochem Int 11:920-930

Saet YuE, Onishhenko TL, Yanin EP (1986) Methodological recommendations for geochemical studies for environmental impact assessing of designed mining enterprises (in Russian). IMGRE, Moscow, $99 \mathrm{p}$

Shuvaeva OV, Gustaytis MA, Anoshin GN (2008) Mercury speciation in environmental solid samples using thermal release technique with atomic absorption detection. Anal Chim Acta 621:148154

Shvartsev SL (1996) General Hydrogeology (in Russian). Nedra, Moscow, 423 p

Skousen J, Simmons J, McDonald LM, Ziemkiewicz P (2002) Acid-base accounting to predict postmining drainage quality on surface mines. J Environ Quality 31(6):2034-2044

Sobek AA, Schuller WA, Freeman JR, Smith RM (1978) Field and laboratory methods applicable to overburden and mine soils. U.S. EPA 600/2-78-054, 203 p

Solomin GA, Krajnov SR (1994) Acidic constituents of natural and acidic waste waters. The processes of these waters neutralization with calcite. Geochem Intern 32(12):1755-1775

Sorokin AA, Ostapenko NS, Ponomarchuk VA, Travin AV (2011) ${ }^{40} \mathrm{Ar} /{ }^{39} \mathrm{Ar}$ age of adularia from veins of the Tokur gold deposit, the Mongolian-Okhotsk orogenic belt, Russia. Geology of Ore Deposits 53(3):264-271 
Stepanov VA, Melnikov AV (2017) Tokur gold-bearing ore-placer cluster of the Amur province: geological and structural features of deposits and prospects for their development. Geology of Ore Deposits 59(2):113-123

Sulfur. Category III method. Chemical methods. Instructions N I-X, 2-X, 3-X (in Russian) (1986) Moscow, $12 \mathrm{p}$

Tauson VL, Menshikov VI, Zubkov VS (1992) Application of the thermal atomic absorption analysis of synthetic crystals to the determination of mercury speciation in minerals. Geochem Intern $8: 1203-1208$

Tauson VL, Zubkov VS, Menshikov VI (1994) Forms of finding mercury in mercury ore formation minerals. Russ Geol Geophys 35(1):54-69

Taylor SR, McLennan SM (1988) Continental crust: its composition and evolution (in Russian). Mir, Moscow, $384 \mathrm{p}$

Vinogradov AP (1957) Geochemistry of rare and trace chemical elements in soils (in Russian). AN SSSR, Moscow, $234 \mathrm{p}$

Water quality standards for water bodies used for fishery, including standards on maximal allowable concentrations of hazardous substances in water of water bodies used for fishery (in Russian). Order of the Ministry of Agriculture of the Russian Federation N 552 of December 13, 2016 as amended on March 10, 2020 (http://www.pravo.gov.ru, 16.06.2020, N 0001202006160052). Access mode: http://docs.cntd.ru/document/420389120

Yanin EP (1993) Ecological geochemistry of mining areas (in Russian). Geoinformmark, Moscow, 50 $\mathrm{p}$ 


\section{Figures}

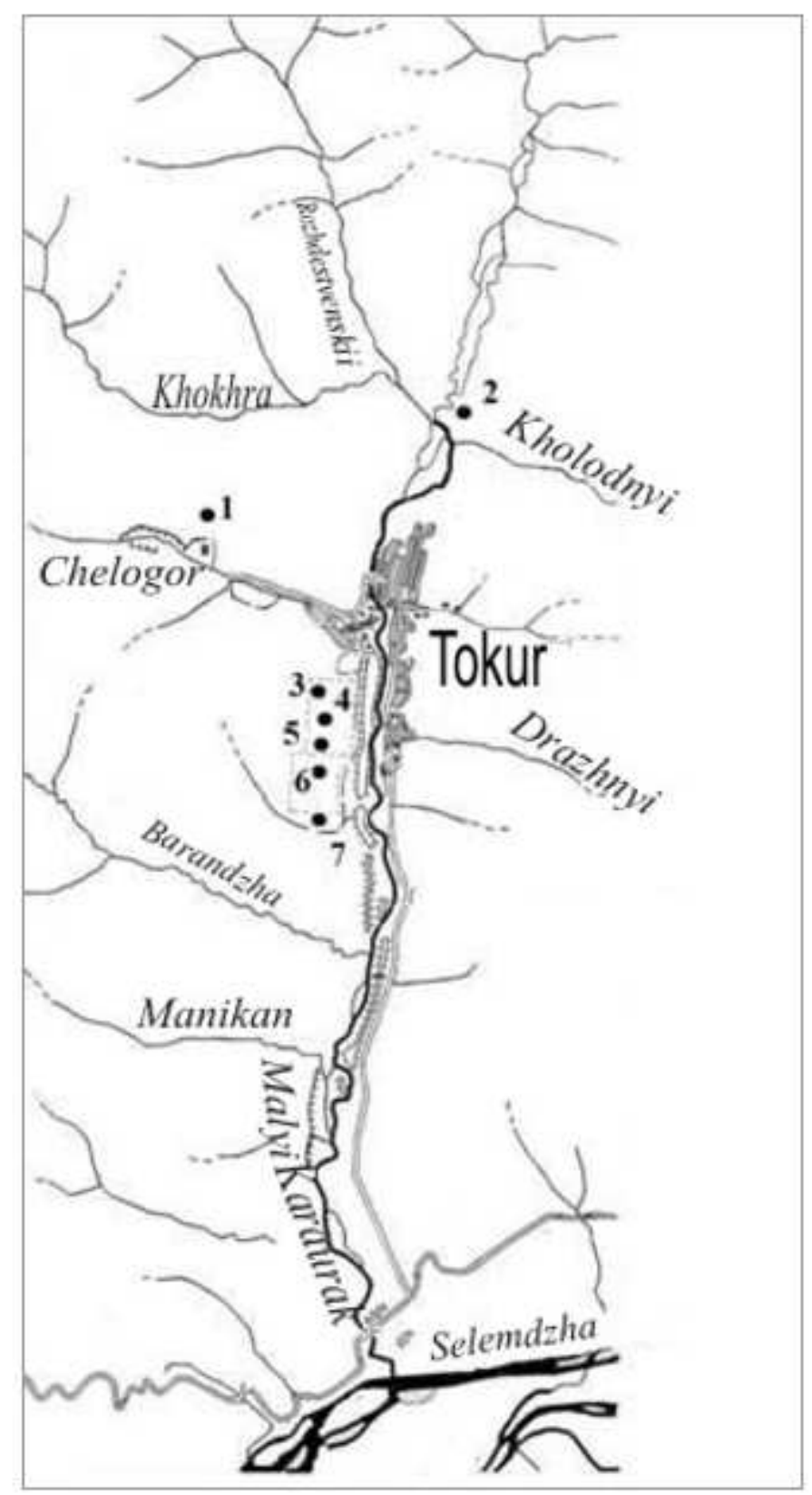

\section{Figure 1}

Map-scheme of the Tokur Mill tailings area: $₫ 2$ - sample points Note: The designations employed and the presentation of the material on this map do not imply the expression of any opinion whatsoever on the part of Research Square concerning the legal status of any country, territory, city or area or of its authorities, or concerning the delimitation of its frontiers or boundaries. This map has been provided by the authors. 



Figure 2

Types of mercury thermoforms 